\title{
Hepatic Flexure
}

National Cancer Institute

\section{Source}

National Cancer Institute. Hepatic Flexure. NCI Thesaurus. Code C12266.

The bend of the colon at the juncture of its ascending and transverse portions. 